\title{
Article
}

\section{Interior Heating and Its Influence on Electric Bus Consumption}

\author{
Kristián Čulík ${ }^{1, *(1)}$, Vladimíra Štefancová ${ }^{2} \mathbb{D}$, Karol Hrudkay ${ }^{1}\left(\mathbb{D}\right.$ and Ján Morgoš ${ }^{1}$ \\ 1 University Science Park, University of Žilina, Univerzitná 1, 01026 Žilina, Slovakia; \\ karol.hrudkay@uniza.sk (K.H.); jan.morgos@uniza.sk (J.M.) \\ 2 Department of Railway Transport, University of Žilina, Univerzitná 1, 01026 Žilina, Slovakia; \\ vladimira.stefancova@fpedas.uniza.sk \\ * Correspondence: kristian.culik@fpedas.uniza.sk; Tel.: +421-41-513-3507
}

Citation: Čulík, K.; Štefancová, V.; Hrudkay, K.; Morgoš, J. Interior Heating and Its Influence on Electric Bus Consumption. Energies 2021, 14, 8346. https://doi.org/10.3390/ en14248346

Academic Editor: Borna Abramovic

Received: 28 October 2021

Accepted: 3 December 2021

Published: 10 December 2021

Publisher's Note: MDPI stays neutral with regard to jurisdictional claims in published maps and institutional affiliations.

Copyright: (C) 2021 by the authors. Licensee MDPI, Basel, Switzerland. This article is an open access article distributed under the terms and conditions of the Creative Commons Attribution (CC BY) license (https:// creativecommons.org/licenses/by/ $4.0 /)$.

\begin{abstract}
This paper focuses on the statistical evaluation of various operating characteristics of electric buses. The data obtained for statistical evaluation come from practice. In this paper, we focus on electricity consumption - an important aspect of electric bus operation. The ambient temperature significantly affects electricity consumption. In this paper, we use applied mathematics-correlation analysis, we accurately identify the effect of temperature on the consumption of the electric bus. Our next goal was to define the relationship between the loss of energy from the battery and driving power. We used regression analysis to describe this relation. Our article also includes an example of the practical use of ANOVA analysis in identifying a statistically significant effect of a particular vehicle on average consumption. We also show results from previous research and compare two different types of electric buses in operation.
\end{abstract}

Keywords: electric buses; heater; mobility; battery; capacity; transportation; ANOVA

\section{Introduction}

Recently, the general interest in electromobility has increased significantly. Now, people connect electromobility with individual transport, mostly with car transport [1,2]. In the future, this probably will change other sectors. There are several studies from agriculture [3], road freight transport [4], or public transport [5] that deal with electric vehicles. There is also a possibility to use electric buses in cities [6] and improve the environmental impact of city transport [7]. Indeed, electric buses offer benefits related to operational, energy, and environmental aspects [8]. In this case, it is primarily a matter of reducing greenhouse gas emissions $[9,10]$. Buses with fuel cells are also environmentally friendly $[11,12]$. We can therefore consider them as the future of public transport. It is for this reason that many scientists are interested in the construction of electric buses. It is necessary to research their power drives, batteries [13], their maintenance [14], and possibilities of recuperation [15]. It is the battery that is an essential part of such a vehicle [16,17]. It is precisely the capacity and life of the battery [18] that currently slows the broader expansion of electric buses in operation. For this reason, the authors of foreign studies often also deal with the energy management of electric buses [19-21].

According to [22], electric buses are a necessary part of sustainable urban development. Compared to buses with a conventional internal combustion engine (ICE), they are more energy-efficient [23]. Their advantage is also in the gradual reduction of dependence on fossil fuels. Electric vehicle batteries have the potential to store energy from renewable sources-wind, sun, and water. This can help to balance fluctuations in energy consumption throughout the day.

In the following paragraphs, there is a literature review of electric vehicles in general. This comprehensive information is necessary because electric buses are a significant subset of electric vehicle. From a microeconomic point of view, battery electric vehicles (BEVs) can be advantageous for the end-user, due to a lower price of electricity compared to the 
price of petrol or diesel [24]. However, electric vehicles have relatively high acquisition costs. Many scientific studies address their cost-effectiveness for households [25-27], often through total cost of ownership (TCO) [28,29]. However, electric vehicles also have other problematic aspects in terms of economy and operation; e.g., [30,31] mentions that they still have insufficient charging infrastructure and insufficient capacity of the BEV batteries. It causes the psychological concern of drivers regarding the charging time, the short range, and the discharge of the BEV while driving [32].

Some authors agree that electric vehicles currently need partial state subsidies $[33,34]$. There is an opportunity for publicly subsidized electric buses in public passenger transport [35]. For this area of public transport, attractiveness is more important than economic efficiency [36]. Vehicles with zero emissions and low noise emissions can improve the quality of urban public transport. This advantage is particularly evident in cities where buses are the only vehicles of the local public transport enterprise. In addition, regular bus transport has the advantage that buses ride on defined routes at predetermined intervals by the schedule [37]. Appropriate planning can thus ensure trouble-free charging of electric buses in various ways, e.g., using a cable or even a pantograph [38]. It is precisely the optimization of the layout of charging stations that several studies have addressed [39-41]. It is also necessary to deploy basic and fast charging stations as optimally as possible [42].

It is clear from the previous text that electric buses have their potential and advantages in regular bus transport, especially in short-distance urban traffic. There is the possibility that frequent charging from prebuilt infrastructure is possible, e.g., charging from the pantograph at the final stop. Our study focuses on currently used electric buses in the Slovak Republic. The Ministry of Economy of the Slovak Republic processes the statistics connected with electromobility [43]. In 2015, only 86 plug-in hybrids (PHEV) and 224 electric cars (BEVs) were registered in Slovakia. In 2020, their number increased significantly to $1021 \mathrm{PHEV}$ and $1582 \mathrm{BEVs}$. We also have information on the composition of these BEVs: 606 motorcycles, 138 all-terrain vehicles (ATVs), 1582 cars, 124 small trucks up to 3.5 tons gross weight, 15 working machines (with registration numbers), and 47 buses (category M3, large bus). The number of electric buses in the Slovak Republic is therefore not so high. In the following chapter, we specify all these buses in detail. On a macroeconomic scale, it is necessary to compare the relative shares of electric buses in the entire vehicle fleet. According to [44], the share of electric buses in Europe was only $0.2 \%$; this is significantly lower than in China (14\%). According to this source, the situation is even more unfavorable in the USA, where the share of electric buses was only $0.03 \%$ in 2018 . If we consider the Slovak Republic, as of 30 June 2020, exactly 8000 buses [45] were registered, of which 2891 were long-distance (36.14\%), 3756 suburban ( $46.95 \%), 1348$ urban $(16.85 \%)$, and 5 special $(0.08 \%)$. The share of electric buses in the total number was therefore only $0.59 \%$.

In this article, we focus on the consumption of electric buses in the Slovak Republic. This essential characteristic has specifics due to large temperature fluctuations in the summer and winter seasons. For example, in 2020, the average daily temperature in Bratislava was more than $25{ }^{\circ} \mathrm{C}$ in summer and less than $-5{ }^{\circ} \mathrm{C}$ in winter [46]. This temperature difference requires air temperature adjustment in the interiors of public transport vehicles. In winter, it is necessary to heat air in buses. On the other hand, air conditioning also makes public transport more attractive.

Our article has several benefits for researchers as well as for practice. As follows from the previous text, Slovak transport companies operate only with several electric buses. We can say that only three transport companies in the whole country have experience with their operation. A significant benefit is the study of the consumption of electric buses, which no-one has published for our conditions. The electric buses have been in operation for a relatively short time. We have managed to obtain and analyze data on their consumption. The published results are helpful for future decisions on investments in electric buses. At present, there is a general concern that electric buses will be unreliable in the winter-at low temperatures with a short range. It is this fact that we will try to verify in the following 
text. We will also focus on the differences in energy intensity caused by different ways of heating electric buses.

\section{Materials and Methods}

The previous section briefly described the theoretical basis of the current state of electric vehicles. The electromobility in the field of public passenger transport is not very developed in the Slovak Republic. There are only 47 electric buses in the Slovak Republic. We managed to identify and classify 46 of these vehicles. We show the list of all mentioned vehicles in Table 1.

Table 1. Electric buses operated in Slovakia. Source: [47], processed by authors.

\begin{tabular}{cccccccc}
\hline Count & Brand & Type & Length (m) & Capacity (pax) & Weight (kg) & $\begin{array}{c}\text { E-Motor } \\
\text { Power (kW) }\end{array}$ & $\begin{array}{c}\text { Max. Speed } \\
(\mathbf{k m} / \mathbf{h})\end{array}$ \\
\hline $18 \times$ & SOR & EBN 11 & 11.10 & $29+63$ & 10,000 & 120 & 80 \\
$5 \times$ & SOR & EBN 10.5 & 10.37 & $19+54$ & 10,200 & 120 & 80 \\
$2 \times$ & SOR & EBN 8 & 8.00 & $16+38$ & 9020 & 120 & 80 \\
$16 \times$ & SOR & NS 12 electric & 12.00 & $33+72$ & 12,350 & 160 & 80 \\
$2 \times$ & Škoda & Perun 26SH01 & 12.00 & $28+42$ & 12,835 & 160 & 80 \\
$1 \times$ & Škoda & Perun 26BB HE & 12.00 & $28+42$ & 12,835 & 160 & 80 \\
$2 \times$ & Troliga & Leonis EV & 12.00 & $30+64$ & 13,000 & 90 \\
\hline
\end{tabular}

* Capacity in sitting + standing passengers.

In our research, we used the procedure that we graphically represent in the flowchart in Figure 1. The source dataset from the bus operator contains information from onboard units (OBUs), drivers, and dispatchers. It was also necessary to obtain temperature data for all analyzed days. The flowchart shows the complete data processing described in this study.

\subsection{Analyzed Vehicles and Input Data Structure}

For this study, we obtained data on the consumption of two SOR EBN 8 electric buses and sixteen SOR ENS 12 electric buses of the Bratislava Transport Company (Bratislava, Slovakia). We also obtained selected data on the consumption of Škoda Perun $26 \mathrm{SH} 01$ vehicles of the Žilina Transport Company (Žilina, Slovakia).

SOR EBN 8 is a city bus for 16 sitting passengers with a total length of $8 \mathrm{~m}$. The drive unit is an asynchronous six-pole motor with a power of $120 \mathrm{~kW}$ and liquid cooling [48]. A battery has a capacity of $172 \mathrm{kWh}$. The air-conditioning system has a cooling capacity of $10 \mathrm{~kW}$. This brand of buses uses independent diesel heating. The first two buses, which we analyze in this article, started their operation in the capital city at the beginning of 2018 . The price of one vehicle was EUR 488,000. The purchase of electric buses was co-financed by the European Regional Development Fund under the Integrated Regional Operational Program 2014-2020 [49]. Vehicles have numbers 3901 and 3902. For both buses, we have traffic records for more than 1200 days.

SOR NS 12 electric is a city electric bus. It is $12 \mathrm{~m}$ long with 29 to 35 seats, according to the design. The drive unit is asynchronous and liquid-cooled, with an output of $160 \mathrm{~kW}$ [50]. Due to the size of the vehicle, the power of the air conditioning is up to $15 \mathrm{~kW}$. The capacity of the traction battery is $242 \mathrm{kWh}$. The bus has independent diesel heating. Bratislava Transport Company uses 16 vehicles of this type. Along with electric buses, the company also supplies the charging infrastructure. The price of one electric bus was EUR 589,000 [51]. 


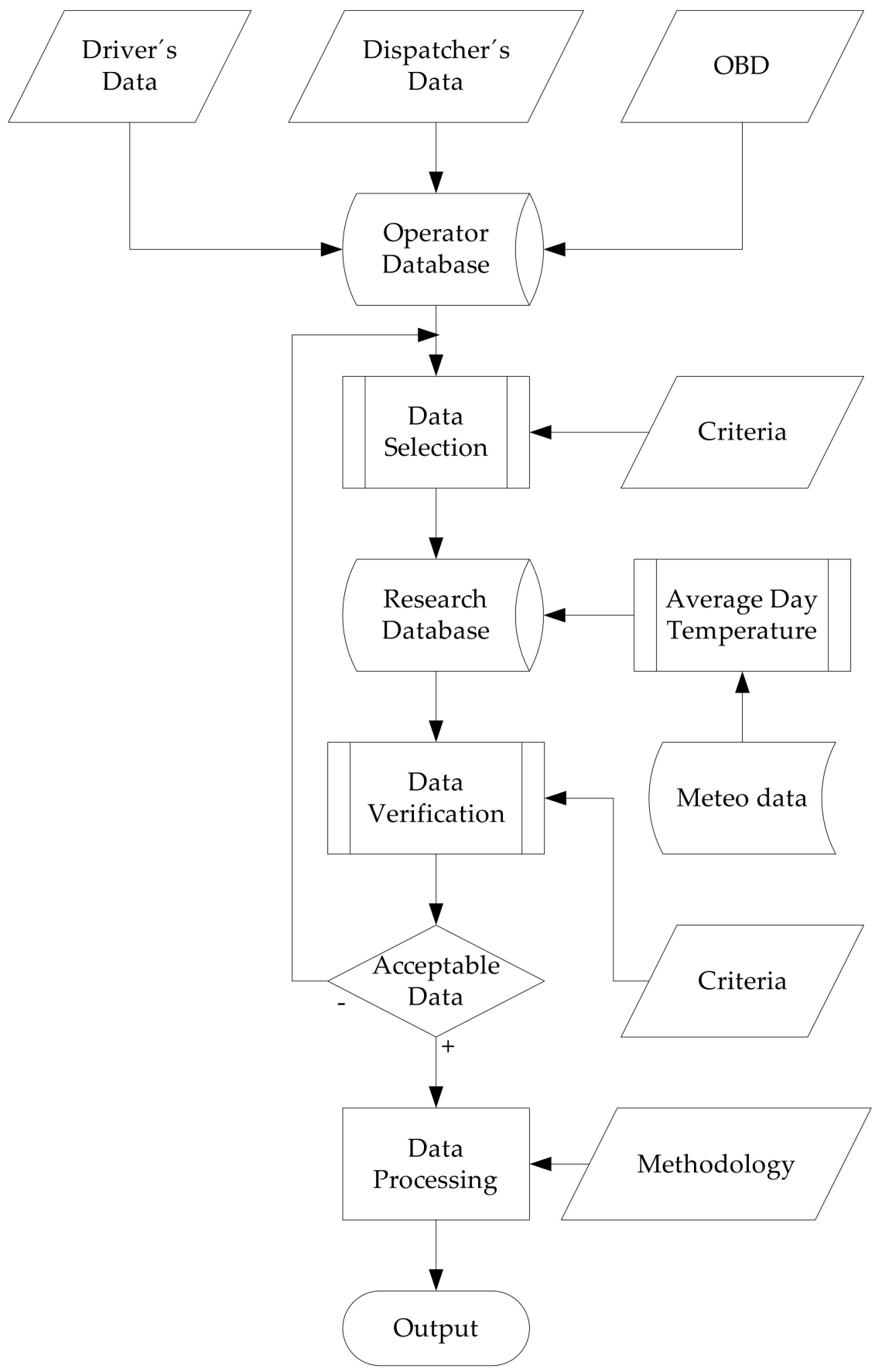

Figure 1. Flowchart showing the complete research process. Source: Processed by authors.

For both types of electric buses operated by Bratislava Transport Company, we have daily records of operating data (the part of the database is attached as Supplementary Materials-Table S1) in the following structure:

- Date-every day, regardless of whether the vehicle was in service, ready for service, or repaired.

- Day-indicates the day of the week.

- Driver's name-only one name is in this column if only one driver used this vehicle during the day. Vehicles used in the two-shift operation have the names of two drivers in this column.

- The following data is entered for both parts of the two-shift operation:

- State of charge (\%) - charge level before the start of the first and second shift. 
$\circ \quad$ Line - an indication of the defined daily route of an electric bus. It is not a single bus line.

- Start and end of the ride (h:min).

- Driving time (h:min).

- Driving distance $(\mathrm{km})$.

- Battery balance after the first and second shift (\%).

$\circ \quad$ Charging after the first and second change $(\mathrm{kWh})$.

- Refueling-all SOR electric buses have independent diesel heating. Therefore, the database also contains the consumption of diesel for heating. Drivers do not refuel buses very often: during winter, once every two days in a volume of about 10 to $60 \mathrm{~L}$.

- Total driving distance-the total distance traveled by the electric bus for a day $(\mathrm{km})$.

- Total electricity consumption (kWh).

- Total driving time (h:min).

- $\quad$ Average consumption $(\mathrm{kWh} / \mathrm{km})$.

- Notes - in this column, it is possible to find a charging station number or information about fast chargers using or charging from the pantograph.

The whole database is quite extensive. Therefore, in the following table (Table 2), we show the number of records and the driving distance of each vehicle. This information is necessary, as it proves that it is not a sample survey, but that we have analyzed the whole period of operation of electric buses from 2018. In the first year, tests of electric buses and their gradual start of the service took place. For that reason, values of driving distance are lower. We should also note that the database ends on 10 May 2021.

Table 2. Input data of operated electric busses. Processed by authors.

\begin{tabular}{|c|c|c|c|c|c|c|}
\hline \multirow{2}{*}{ Vehicle Code } & \multirow{2}{*}{ Type } & \multirow{2}{*}{ Records } & \multicolumn{4}{|c|}{ Annual Driving Distance (km) } \\
\hline & & & 2018 & 2019 & 2020 & 2021 \\
\hline V3001 & NS 12 electric & 856 & 36,640 & 60,340 & 45,311 & 23,658 \\
\hline V3002 & NS 12 electric & 993 & 44,380 & 48,538 & 62,754 & 18,430 \\
\hline V3003 & NS 12 electric & 846 & 14,598 & 57,668 & 65,442 & 20,660 \\
\hline V3004 & NS 12 electric & 804 & 21,906 & 57,978 & 57,712 & 8464 \\
\hline V3005 & NS 12 electric & 852 & 14,542 & 55,050 & 58,795 & 22,967 \\
\hline V3006 & NS 12 electric & 870 & 15,643 & 59,592 & 65,487 & 20,871 \\
\hline V3007 & NS 12 electric & 884 & 12,520 & 54,263 & 73,923 & 24,140 \\
\hline V3008 & NS 12 electric & 807 & 9114 & 56,555 & 61,542 & 13,585 \\
\hline V3009 & NS 12 electric & 751 & 9725 & 55,046 & 44,073 & 20,796 \\
\hline V3010 & NS 12 electric & 663 & 1770 & 28,964 & 64,147 & 24,316 \\
\hline V3011 & NS 12 electric & 785 & 7795 & 53,198 & 51,643 & 23,275 \\
\hline V3012 & NS 12 electric & 796 & 7279 & 57,015 & 53,111 & 23,157 \\
\hline V3013 & NS 12 electric & 830 & 7204 & 56,545 & 58,588 & 24,485 \\
\hline V3014 & NS 12 electric & 762 & 2677 & 47,481 & 61,085 & 23,685 \\
\hline V3015 & NS 12 electric & 800 & 5326 & 53,157 & 58,167 & 19,036 \\
\hline V3016 & NS 12 electric & 783 & 6730 & 50,969 & 54,156 & 23,247 \\
\hline V3901 & EBN 8 & 867 & 28,691 & 25,497 & 30,575 & 10,032 \\
\hline V3902 & EBN 8 & 936 & 22,626 & 36,196 & 36,317 & 11,826 \\
\hline \multicolumn{2}{|c|}{ Total } & 14,885 & 269,166 & 914,052 & $1,002,829$ & 356,629 \\
\hline
\end{tabular}

\subsection{Data Collection}

All the data we used for the statistical analysis came from two places. The operational department of the Bratislava Transport Company provided complete information on the daily operation of electric buses for the entire period of their service. This data is comprehensive and obtained from various sources:

- Information such as the state of charge of batteries, driving distance, battery balance, and charging in $\mathrm{kWh}$ are from electronic control units (ECU) of each electric bus.

- On the other hand, the driver writes down the exact volume of refueling heating diesel. 
- There are also parameters that the dispatcher writes down. He decides the names of the drivers who will drive on each work shift. He also determines the exact "line" (not the single bus line, but the complete set of bus connections per one work shift).

We also obtained operation data for two electric buses owned by Žilina Transport Company (Žilina, Slovakia). In this case, the data have a substantially different structure:

- Identification data (bus number, VIN_vehicle identification number) and time range of data entry.

- Total travelled distance in $\mathrm{km}$.

- Total electric energy in kWh:

- Charged via pantograph.

- Charged via the power cable.

- Total consumption divided into:

- Internal consumption with energy redistribution: clean traction, auxiliary drives, heating, air conditioning, energy for $24 \mathrm{~V}$ appliances.

- External consumption.

- The data log also contains daily data of charged energy, mileage, consumption, and number of battery balances.

\subsection{Research Hypothesis}

In this article, we test the following hypotheses:

Hypothesis 1 (H1). There is a relationship between the ambient temperature and the electricity consumption of an electric bus heated by electric heaters in the winter months (Pearson's correlation coefficient $|R|>0.6)$. This dependence only arises if the vehicle has electric heaters, because they have a direct effect on the total consumed energy.

The consumption of the electric bus is significantly affected by heating or air conditioning. In the previous research, we focused on analyzing the operating characteristics of the Škoda Perun 26SH01 electric buses. We want to identify the dependence of consumption and ambient temperature, so we add two more related hypotheses:

Hypothesis 2 (H2). Electric buses with independent diesel heating show no or little dependence (Pearson correlation coefficient $|R|<0.3$ ).

Hypothesis 3 (H3). There is a relationship between the ambient temperature and the electricity consumption of the air-conditioned electric bus in the summer months.

Hypothesis 4 (H4). Differences in average electricity consumption are statistically significantly different for different vehicles. For this, we use the ANOVA tool. We aim to find out whether the value of the independent quantity - a specific vehicle - has a statistically significant effect on the value of the dependent variable; in this case, the vehicle consumption in $\mathrm{kWh} / \mathrm{km}$.

The last and significant task is to compile the most accurate equation of the dependence of two quantities - driving distance and energy consumption from the battery [52]. We express this dependence graphically and try to capture this dependence with a suitable function using regression analysis. This role is most important for planning the performance of electric buses in practice [53]. At present, the capacity of batteries in vehicles is still not sufficient. In addition, according to [54-56], it gradually decreases.

For statistical analysis and verifying hypotheses, we use advanced statistical methods described in the following subchapters. We have data on the operation of electric buses in Bratislava for each calendar day, including Saturdays, Sundays, and holidays. On these days, some vehicles were not in service. Therefore, it was necessary to filter all records of the database. There were also days with very short driving distance, which should not 
be involved. These could be related to, for example, vehicle repair or a test drive after repair. The last problem was the incorrect entries. They caused extreme values of electricity consumption (low or high). We did not consider them.

\subsection{Correlation Analysis}

Correlation analysis deals with the evaluation of the dependence of two random variables. This method evaluates the intensity of the relationship. The dependencies, which it examines, are primarily linear. It is a measure of a linear relationship. The well-known fact is that correlation is not causality. Quantities that correlate with each other can be interdependent. However, we cannot say with certainty that they are conditional.

Covariance cov $x y$ describes the existence of a linear relationship between two variables. With the covariance, we can evaluate the relationship between two random variables $\mathrm{x}$ and $\mathrm{y}$. The basic equation for its calculation is Equation (1):

$$
\operatorname{cov} x y=\frac{1}{n} \sum_{i=1}^{n}\left(x_{i}-\bar{x}\right)\left(y_{i}-\bar{y}\right)=\overline{x y}-\bar{x} \cdot \bar{y}
$$

Values of covariance are in the interval $(-\infty ;+\infty)$. It gives us only information about the dependence between the variables (existing or not). Usually, we want to calculate the dependence intensity. Therefore, we use the correlation analysis:

- The result of correlation analysis has values from the interval $\langle-1 ; 1\rangle$ or $\langle 0 ; 1\rangle$.

- As the dependence increases, the correlation coefficient also increases.

- The correlation coefficient must be independent (variables can have different units).

If we want to obtain the correlation coefficient, we need to divide the covariance by standard deviations of variables. We can use the following Equation (2):

$$
R=\frac{\operatorname{cov} x y}{s_{x} s_{y}}=\frac{n \sum x y-\sum x \sum y}{\sqrt{\left[n \sum x^{2}-\left(\sum x\right)^{2}\right] \cdot\left[n \sum y^{2}-\left(\sum y\right)^{2}\right]}}
$$

Typical correlation coefficient has values from the interval $\langle-1 ; 1\rangle$. It measures the two-tailed linear dependence of two variables. There can be only three possible results according to the value of the coefficient:

- $\mathrm{R}=0 \Leftrightarrow$ variables $\mathrm{X}$ and $\mathrm{Y}$ are not linearly dependent.

- $\mathrm{R}>0 \Leftrightarrow$ a direct linear relationship between the variables $\mathrm{X}$ and $\mathrm{Y}$.

- $\mathrm{R}<0 \Leftrightarrow$ an indirect linear relationship between the variables $\mathrm{X}$ and $\mathrm{Y}$.

According to [57], the interpretation of the correlation coefficient depends on the context. For example, the correlation coefficient of 0.8 is very high for psychological research but very low for physics. In 1988, Cohen [58] described the correlation according to the coefficient value as follows:

- The correlation in the absolute value below 0.1 is trivial.

- The correlation in the range of 0.1 to 0.3 is small.

- In the interval of 0.3 to 0.5 it is medium.

- At values above 0.5 it is high.

- The correlation of 0.7 to 0.9 is very high.

- A correlation in the range of 0.9 to 1.0 is almost perfect.

\subsection{ANOVA Analysis}

ANOVA analysis, or analysis of variance, investigates the relationship between nondependent and dependent variables, especially when evaluating experimental data. If we examine the effect of only one factor on one or more dependent variables, it is a single-factor ANOVA analysis. It assumes a single explanatory variable. In multivariate analysis of variance (MANOVA), we can have several explanatory variables simultaneously [59]. 
To determine whether the observed variability of the variable $Y$ depends on the affiliation of the values in the groups, we break down the overall variability into components corresponding to different sources of variability. We express variability in the one-dimensional case using the sums of squares, and in the multidimensional case using matrices in which the sums of squares form the main diagonal. The analysis of the variance model is a specific case of the general linear model (GLM). Hypotheses about the influence of factors are a special case of the general linear hypothesis about the parameters of the model [60].

\subsection{Regression Analysis}

By regression analysis, we determine the dependence of the input $\left(X_{1}, X_{2}, \ldots\right)$ on the output $(\mathrm{Y})$. The regression analysis aims to estimate this relationship as accurately as possible. In contrast to correlation analysis, we are not just looking for a linear relationship. Thus, we try to overlay the measured data with the curve, which should describe and forecast the behavior of a sample of the measured data. In the simplest case, it will be a linear relationship, a linear regression.

When we want to select the correct regression function, we use the method of least squares. It should be such a function that its values are close to our data sample. It does not have to be linear. In some cases, we can use quadratic, cubic, logarithmic, or another function.

An indicator of the correctness of the model is the so-called coefficient of determination R2. This indicator of model adequacy expresses what percentage of output variability (Y) is caused by our inputs $\left(X_{1}, X_{2}, \ldots\right)$. We also know the adjusted coefficient of determination $\mathrm{R}^{2}$ (adj). It considers the number of predictors in the model.

\section{Results}

The first task was to filter the whole database of daily records. There were many empty lines for the days when the vehicle was not in service. During these days, the bus was technically ready (weekends, holidays, or other days when the bus was unnecessary) or repaired (service, technical inspections, etc.). It was equally important to remove any faulty records. These were raised due to errors on the measuring device or driver's mistake. After this data cleaning, 14,888 data records remained available for the analysis of 18 electric buses. The production data of three analyzed electric buses are in Table 3. According to the statements of electric bus producers Skoda Transportation (Plzen, Czech Republic) and SOR (Libchavy, Czech Republic), the batteries described in the table should have similar production years as the bus itself.

Table 3. Production data of analyzed electric buses. Source: [48,50,61], processed by authors.

\begin{tabular}{|c|c|c|c|c|c|c|c|}
\hline Brand & Type & Price [EUR] & $\begin{array}{c}\text { Production } \\
\text { Year }\end{array}$ & E-Motor Type & $\begin{array}{c}\text { Battery } \\
\text { Capacity } \\
{[\mathrm{kWh}]}\end{array}$ & $\begin{array}{l}\text { Battery } \\
\text { Type }\end{array}$ & $\begin{array}{l}\text { Battery } \\
\text { Producer }\end{array}$ \\
\hline SOR & EBN 8 & 488,000 & 2017 & $\begin{array}{l}\text { Asynchronous } \\
\text { six-pole, } \\
\text { liquid-cooled }\end{array}$ & 172 & Lithium-ion & $\begin{array}{l}\text { Winston } \\
\text { battery }\end{array}$ \\
\hline SOR & $\begin{array}{l}\text { NS } 12 \\
\text { electric }\end{array}$ & 589,000 & $2017 / 2018$ & $\begin{array}{l}\text { Asynchronous } \\
\text { six-pole, } \\
\text { liquid-cooled }\end{array}$ & $242 / 388$ & Lithium-ion & $\begin{array}{l}\text { Winston } \\
\text { battery }\end{array}$ \\
\hline Škoda & $\begin{array}{l}\text { Perun } \\
\text { 26SH01 }\end{array}$ & 576,500 & 2018 & Asynchronous & 222 & $\begin{array}{c}\text { Lithium Cobalt } \\
\text { Manganese } \\
\text { Nickel Oxide }\end{array}$ & EVC Group \\
\hline
\end{tabular}

\subsection{Electric Buses with Electric Heaters}

In the previous research, we focused on other types of electric buses. These two vehicles, operated by the Transport Company of the City of Žilina (Žilina, Slovakia), have the type designation Škoda Perun 26SH01. These vehicles have lower emissions because 
they do not have independent diesel heating. We found that the impact of air conditioning on consumption is negligible overall. It was possible to make a regression analysis for the relationship between temperature and overall electricity consumption. We tested the suitability of chosen regression equation with the coefficient of determination. The linear regression explained approximately $77.4 \%$ of the values $\left(R^{2}=0.774\right)$. Its equation was $y=3.71-0.08 x$. Then, we tried to explain the relationship with the exponential function. It was possible to explain more than $80 \%$ of the values $\left(R^{2}=0.819\right)$. Its graphical representation is in Figure 2. Nodes of winter values are blue, and summer values are black.

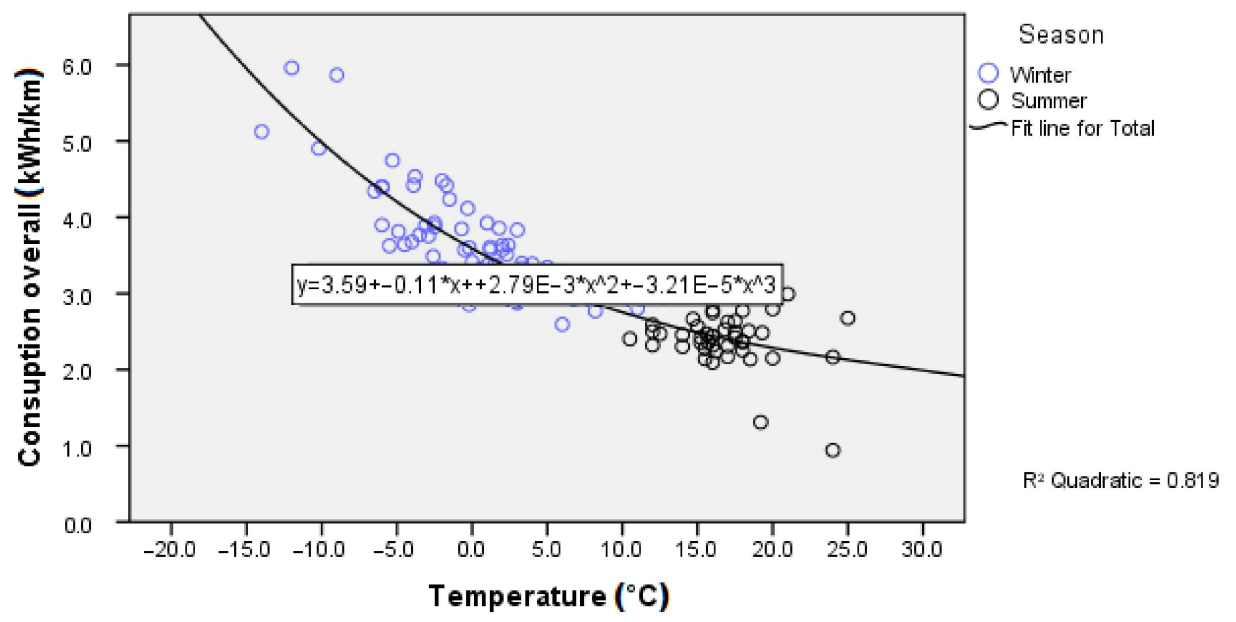

Figure 2. Dependence of temperature and overall consumption. Source: Processed by authors.

Figure 2 shows a graph of average electricity consumption. On the left side are four extreme values of electricity consumption. We should state that not just low temperatures but also high temperatures caused this consumption. The traveled distance of these four days was quite low. During the data cleaning, we had a minimum daily distance necessary for further evaluation. However, the electric bus traveled this minimal distance during these four days. We should also mention that the figure shows the total consumption that includes the energy for traction e-motor, heating, and for all other electrical appliances in the bus. Our data are from the diagnostic system Astrid, Škoda Electric (Škoda, Plzeň, Czech Republic).

The results of the second part of the research were quite different. We focused on the relationship between the electricity consumption of the e-motor and the ambient temperature. We could explain only about $25 \%$ of all values with the regression analysis. A low correlation coefficient $(\mathrm{R}=-0.496)$ caused these results. With linear regression, we obtained the coefficient of determination $R^{2}=0.246$. Better results produced the exponential function. The coefficient of determination was $R^{2}=0.268$.

\subsection{Electric Buses with Diesel Heaters}

In this article, we deal with electric buses that use independent diesel heating. The following figure (Figure 3) shows the total diesel consumption during the operation of all electric buses for the entire period. The consumption of diesel increases significantly in the winter months. We show average temperatures for each depicted month. These values are above $0{ }^{\circ} \mathrm{C}$. For detailed calculations and analysis, we used average daily temperatures. These temperatures were calculated by the standard Equation (3).

$$
t_{d}=\frac{t_{7}+t_{14}+2 * t_{21}}{4}
$$

In Equation (4), $t d$ is an average daily temperature, $t_{7}$ is the temperature at 7:00 a.m., $t_{14}$ is the temperature at 2:00 p.m., and $t_{21}$ is the temperature at 9:00 p.m. 


\section{Diesel consumption of all electric buses and average monthly} temperature in place of operation

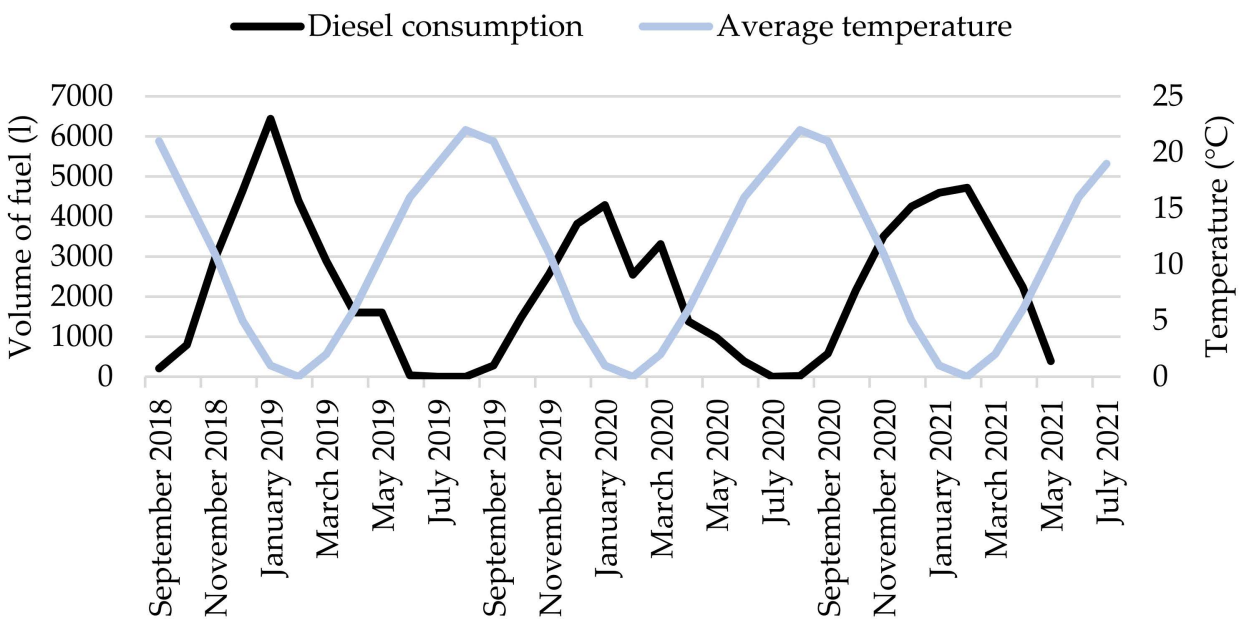

Figure 3. Volume of fuel used for heating in months with average monthly temperatures. Source: Processed by authors; temperatures from [62].

Figure 4 shows the comparable average consumption of a randomly selected electric bus with diesel and electric heating. The picture only captures the electricity consumption of the traction e-motor. Regardless of the method of heating, consumption increases in the cold winter months.

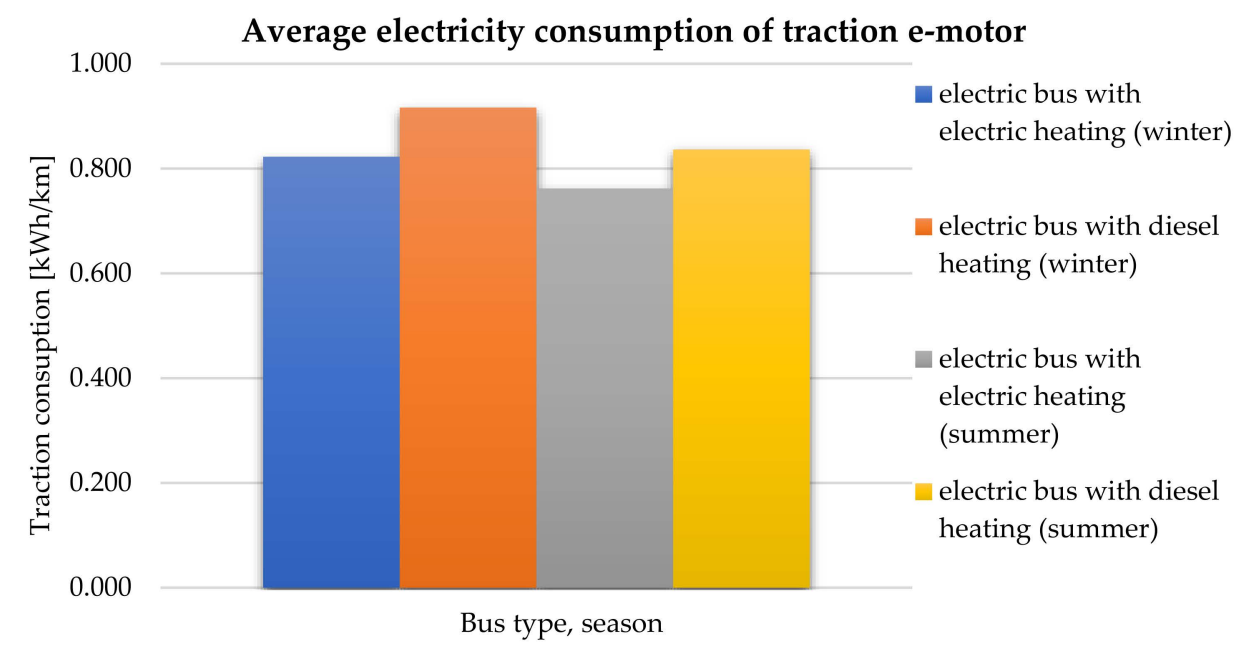

Figure 4. Average electricity consumption of traction e-motor for both types of electric bus. Source: Processed by authors.

Figure 5 compares the electricity consumption for heating in the summer and winter months. In the temperature conditions of Slovakia, it is necessary to heat the passenger area even during the summer months in the early morning hours. Therefore, we could calculate the electricity and fuel consumption also in the summer months. Electricity and fuel consumption are difficult to compare, so the chart has different left and right axes.

To answer the first hypothesis, we must also look at the electricity consumption of individual electric buses. We paired its almost 15,000 daily values with the daily average temperature at the place of operation of electric buses in Bratislava. Subsequently, we used correlation analysis to calculate the coefficients of correlation between consumption and temperature. Due to the independent heating, the coefficients reached significantly lower 
values. For better comparison, we expressed these values graphically for $12 \mathrm{~m}$ vehicles V3001 to V3016 and for $8 \mathrm{~m}$ vehicles V3901 and V3902 (Figure 6).

\section{Average electricity and fuel consumption of heating}

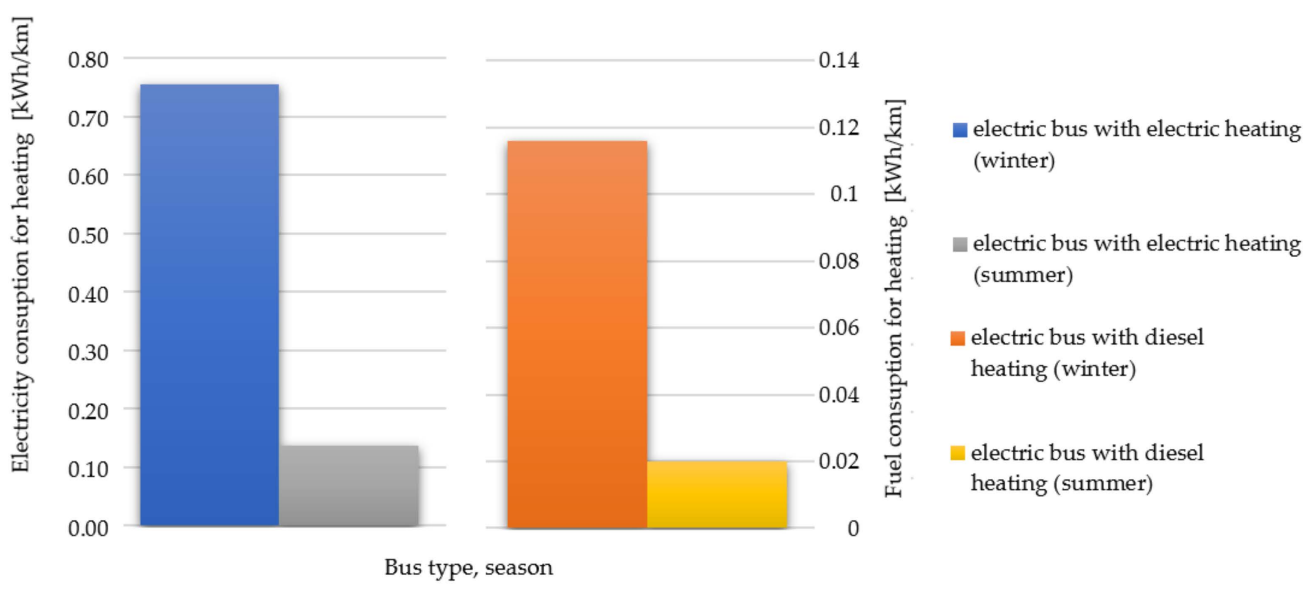

Figure 5. Average electricity and fuel (diesel) consumption of heating system for both types of electric bus. Source: Processed by authors.

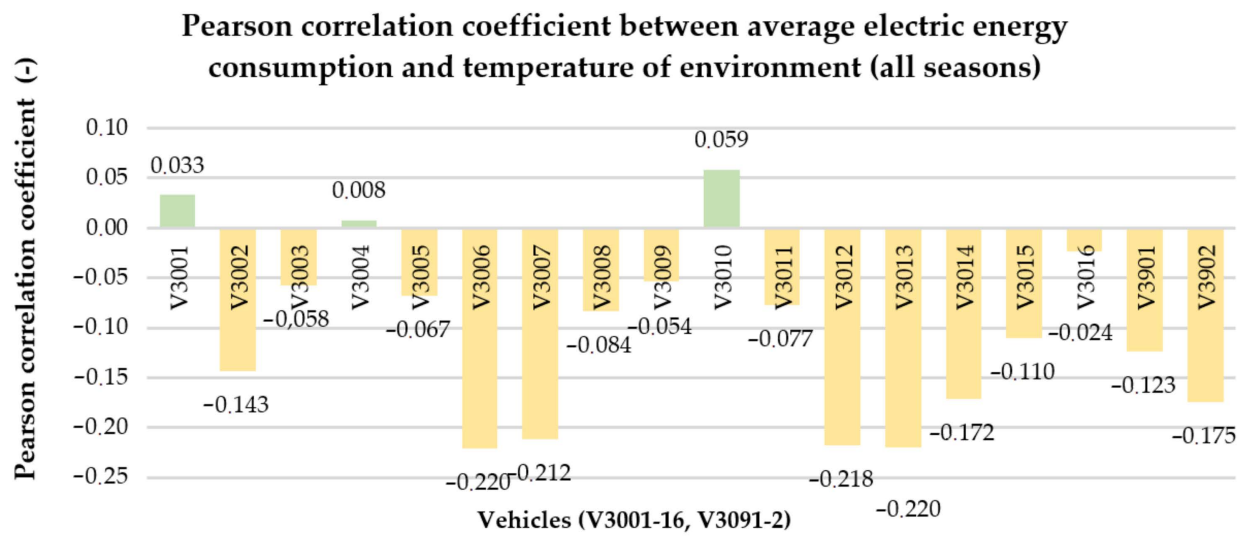

Figure 6. Volume of fuel used for heating in months with average temperatures. Source: Processed by authors; temperatures from [63].

Figure 6 shows that the Pearson correlation coefficient has mostly negative values for individual vehicles (indirect dependence). Its value is up to 0.3. Therefore, we can draw two conclusions on this part:

- The negative conclusion is that it is not possible to predict the consumption of an electric bus with independent diesel heating based on ambient temperatures.

- A positive conclusion is the unconfirmed concern about the higher electricity consumption during winter.

A related issue is an operation in the significantly warm (summer) months. It is the period when buses use air conditioning units. For this reason, we selected only three summer months for further correlation analysis-June, July, and August. Although the calculation confirmed the expected positive value, the value $R=0.1284$ was too low. We can therefore conclude that there is no linear dependence.

Another part of the research is a comparison of vehicle consumption. For the further operation of electric buses, it is necessary to examine other relationships. We want to know if a particular vehicle affects average consumption. For these purposes, we use the ANOVA analysis. This tool determines whether the independent variable has a significant impact on the value of a dependent variable. In this case, each vehicle has a different number of values (cleaned days in operation). For this reason, we used ANOVA: single factor. We 
processed analysis separately for vehicles V3001 to V3016, and subsequently for vehicles V3901 and V3902.

Tables 3 and 4 show the results of the ANOVA analysis. The null hypothesis (applies if $\mathrm{F}<\mathrm{F}$ crit) in this case reads as follows: the mean values are the same, i.e., the value of the independent variable (specific vehicle) does not affect the value of the dependent variable (average electricity consumption in $\mathrm{kWh} / \mathrm{km}$ ). The alternative hypothesis (applies if $\mathrm{F}>\mathrm{F}$ crit) reads as follows: the mean values of the selection differ, i.e., the value of the independent variable affects the value of the dependent variable. In both cases, we have confirmed that F > F crit $(46.95>1.67$ for longer buses-Table 4; $40.24>3.85$ for short buses-Table 5). In this case, we can therefore claim that a particular vehicle affects the average consumption expressed in $\mathrm{kWh}$ per kilometer within the specified reliability value. In the ANOVA analysis (Tables 4-6), we used the following abbreviations:

- SS-sum of squares.

- $\mathrm{df}-$ degrees of freedom.

- MS-mean squares.

- $\mathrm{F}$-variation within the samples.

Table 4. ANOVA analysis for 16 operated electric buses with length of $12 \mathrm{~m}$. Processed by authors.

\begin{tabular}{ccccccc}
\hline $\begin{array}{c}\text { Source of } \\
\text { Variation }\end{array}$ & SS & df & MS & F & $p$-Value & F Crit \\
\hline $\begin{array}{c}\text { Between Groups } \\
\text { Within Groups }\end{array}$ & 50.45908 & 15 & 3.363938 & 46.95345 & $1.5 \times 10^{-136}$ & 1.667151 \\
$\quad$ Total & 986.5611 & 13066 & 0.071644 & & & \\
\hline
\end{tabular}

Table 5. ANOVA analysis for two operated electric buses with length of $8 \mathrm{~m}$. Processed by authors.

\begin{tabular}{ccccccc}
\hline $\begin{array}{c}\text { Source of } \\
\text { Variation }\end{array}$ & SS & df & MS & F & $p$-Value & F Crit \\
\hline Between Groups & 0.935762 & 1 & 0.935762 & 40.23961 & $2.83 \times 10^{-10}$ & 3.846619 \\
Within Groups & 41.95156 & 1804 & 0.023255 & & & \\
Total & 42.88732 & 1805 & & & & \\
\hline
\end{tabular}

Table 6. Regression analysis of travelled distance by electric buses for summer season (1902 observations). Processed by authors.

\begin{tabular}{cccccccc}
\hline \multicolumn{2}{c}{ Regression Statistics } & ANOVA & df & SS & MS & F & Signific. F \\
\hline Multiple R & 0.7519 & Regression & 2 & 1588.390 & $794,194.80$ & 1234.68 & 0 \\
R Square & 0.5653 & Residual & 1899 & 1221.516 & 643.24 & & \\
Standard Error & 25.3622 & Total & 1901 & 2809.906 & & & \\
\hline & \multirow{2}{*}{ Coefficients } & \multirow{2}{*}{ t Stat } & $\boldsymbol{p}$-Value & Lower & $\mathbf{U p p e r}$ & Lower & Upper \\
& & & & $\mathbf{9 5 \%}$ & $\mathbf{9 5 \%}$ & $\mathbf{9 5 . 0 \%}$ & $\mathbf{9 5 . 0 \%}$ \\
\hline Intercept & -4.9919 & -0.9845 & 0.3250 & -14.9363 & 4.9525 & -14.9363 & 4.9525 \\
Battery & 195.7488 & 47.1760 & 0.0000 & 187.6111 & 203.8865 & 187.6111 & 203.8865 \\
Temperature & 1.4073 & 6.7692 & 0.0000 & 0.9996 & 1.8150 & 0.9996 & 1.8150 \\
\hline
\end{tabular}

In the last part of our research, we look for the equation of the dependence of driving distance on the consumed electricity. Even before this part of the analysis, we cleaned data. In practice, the transport company uses electric buses in two work shifts. The driver of the first (morning) work shift takes the vehicle. Before starting, he writes down the initial state of batteries. After his work shift, he records the number of kilometers traveled and the battery state after arriving at the depot. Subsequently, the battery charging starts. The driver coming for the afternoon shift ends the charging, writes the initial state of charge in percent, and then starts his work shift. When finished, he also records the number of kilometers traveled and the percentage of battery charge. From these two values, we can 
calculate the discharge of batteries in percentage. For this reason, the total "consumed" energy can be higher than 100\% due to bus recharging during the day.

In the following tables and graphs, the driving distance on the $\mathrm{Y}$-axis is an explanatory variable, and the percentage charge of the traction batteries on the $\mathrm{X}$-axis is an explanatory variable. We divided the predictions of driving distance into winter and summer periods. In the following figure (Figure 7), we estimated the dependence of battery consumption and driving distance as a linear line. As you can see, its equation is $y=200.86 x+22.216$. The correlation coefficient, which expresses the strength of the linear dependence, is at the level $\mathrm{R}=0.7448$.

\section{Travelled distance and energy consumption (summer} season)

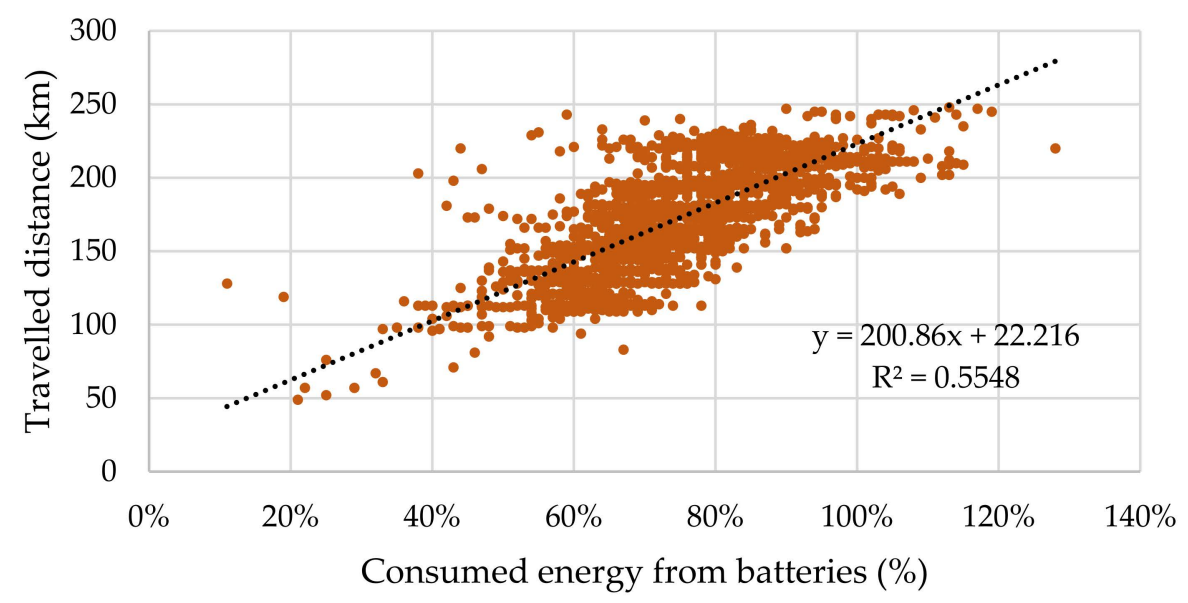

Figure 7. Relationship between consumed energy from batteries and travelled distance for summer season. Source: Processed by authors; temperatures from [63].

Previous research shows that as the ambient temperature increases in the summer months, consumption also increases, in part. This is due to the air conditioning. All electric buses that we monitored have an air-conditioning unit. For this reason, we added another independent variable to the linear regression analysis, namely temperature. Table 5 shows the results of the regression analysis.

In this case, we could explain $56.53 \%$ of the values, which is more than $55.48 \%$. The result is thus an Equation (4) for determining the driving distance of an electric bus for the summer period.

$$
y=195.75 \cdot x_{1}+1.41 \cdot x_{2}-4.99
$$

In this equation, $x_{1}$ is the percentage state of battery charge and $x_{2}$ is the temperature in ${ }^{\circ} \mathrm{C}$. In the same way, we prepared data for the winter months of bus operation. We analyzed 2374 vehicle days in three months (December, January, and February).

The following figure (Figure 8) shows a simple two-factor dependence of electricity consumption (expressed as a percentage of battery capacity) and driving distance in kilometers. Again, it is possible to describe this dependence with the equation. It explains about $52.54 \%$ of the values.

In this case, we also tried to add the ambient temperature to the overall calculation of the traveled distance. Table 7 shows the results of the regression analysis.

Using a new independent variable (ambient temperature), we slightly increased the accuracy of the resulting equation from $52.54 \%$ to $54.79 \%$. The resulting equation based on the regression analysis has the form of Equation (5), in which $x_{1}$ is the state of charge (percentage value) and $x_{2}$ is the temperature in ${ }^{\circ} \mathrm{C}$.

$$
y=204.61 \cdot x_{1}+1.74 \cdot x_{2}-8.53
$$


Travelled distance and percentage of batteries (summer season)

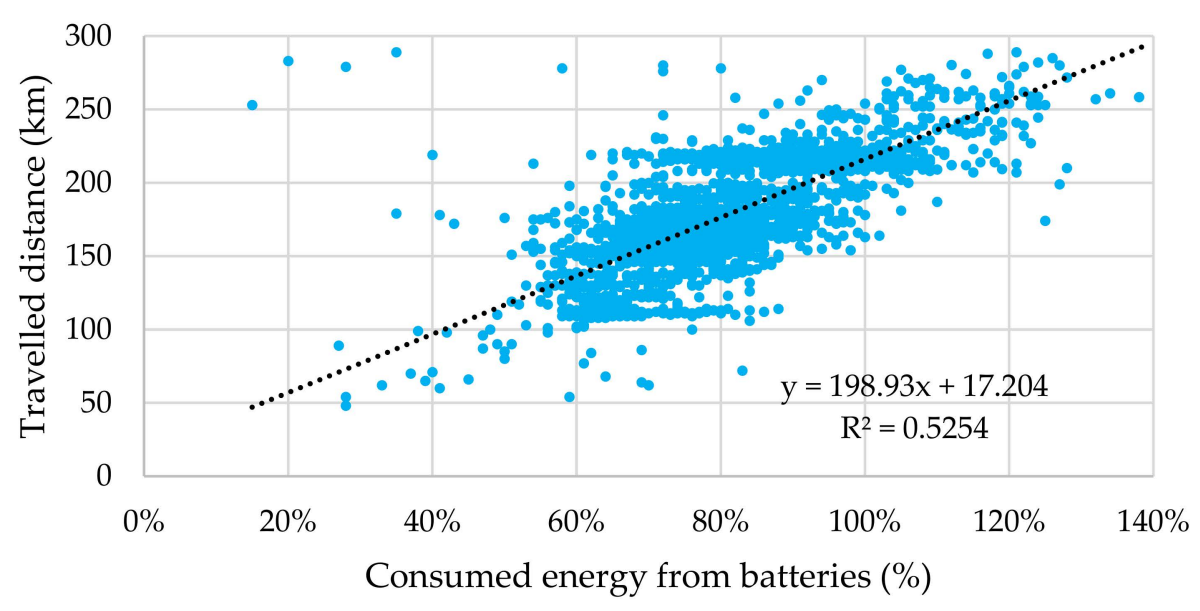

Figure 8. Relationship between consumed energy from batteries and travelled distance for winter season. Source: Processed by authors; temperatures from [63].

Table 7. Regression analysis of travelled distance by electric buses for winter season (2374 observations). Processed by authors.

\begin{tabular}{cccccccc}
\hline \multicolumn{2}{c}{ Regression Statistics } & ANOVA & df & SS & MS & F & Signific. F \\
\hline Multiple R & 0.7402 & Regression & 2 & 2284.778 & 1142.39 & 1436.99 & 0 \\
R Square & 0.5479 & Residual & 2371 & 1884.920 & 794.99 & & \\
Standard Error & 28.1956 & Total & 2373 & 4169.698 & & & \\
\hline & \multirow{2}{*}{ Coefficients } & \multirow{2}{*}{ Stat } & $\boldsymbol{p}$-Value & Lower & $\mathbf{U p p e r}$ & Lower & Upper \\
& & & & $\mathbf{9 5 \%}$ & $\mathbf{9 5 \%}$ & $\mathbf{9 5 . 0 \%}$ & $\mathbf{9 5 . 0 \%}$ \\
\hline Intercept & 2.6450 & 0.0082 & 2.2055 & 14.8506 & 2.2055 & 14.8506 & 4.9525 \\
Battery & 53.4885 & 0.0000 & 197.1133 & 212.1162 & 197.1133 & 212.1162 & 203.8865 \\
Temperature & 10.8725 & 0.0000 & 1.4250 & 2.0521 & 1.4250 & 2.0521 & 1.8150 \\
\hline
\end{tabular}

\section{Discussion}

In this article, we focused on heating of electric buses. From a similar study [64] it is obvious that there are four types of bus heating. Fuel heaters burn a liquid fuel and provide the released heat of the burning process to the air, or in most cases, to the vehicle's cooling fluid. Electric heaters transform electric energy into thermal energy, which is transferred to the air or the cooling fluid. The source describes two other possibilities. The electric bus can have heat pumps that use a refrigerant circle that is mostly driven by an electric compressor [65]. The compressor uses the electricity from the traction battery of the bus. The last option for heating is a thermal energy storage system. The stored heat is used for interior heating to keep the electric energy stored in the battery for driving.

We focused mainly on diesel heating because most electric buses operated in Slovakia have this type of interior heating. Based on the mathematical-statistical analysis of the obtained operational data, we can critically evaluate each hypothesis.

First, we verified hypothesis H1: There is a relationship between the ambient temperature and the electricity consumption of the electric bus heated by electric heaters in the winter months (Pearson's correlation coefficient $|R|>0.6$ ). The electric heaters have a direct effect on the total consumed energy. In previous research, we analyzed the characteristics of Škoda Perun vehicles operated by the Žilina Transport Company. The correlation coefficient between total electric bus consumption and ambient temperature was -0.880 at a significance level of 0.01 (two-tailed test). We can accept this hypothesis. 
We also focused on the related Hypothesis H2: Electric buses with independent diesel heating show no or little relationship (Pearson correlation coefficient $|R|<0.3$ ). We confirmed this hypothesis, too. The absolute value of the correlation coefficient between ambient temperature and consumption is, for all vehicles, up to 0.3 . The limitations of these outputs are other variables that could affect the result-a specific bus line or a specific driver.

We also examined whether the air conditioning of the electric bus had a significant effect on consumption in the summer months. The power of the air conditioning units is $10 \mathrm{~kW}$ for short buses and $15 \mathrm{~kW}$ for long buses. Given that the calculated correlation coefficient had a value of only $\mathrm{R}=0.1284$, we can reject hypothesis $H 3$ : There is a relationship between the ambient temperature and the electricity consumption of the air-conditioned electric bus in the summer months.

Furthermore, we investigated the statistical significance of a particular vehicle to average consumption (Hypothesis H4: Differences in average electricity consumption are statistically significantly different for different vehicles). We used the ANOVA analysis for this purpose and found that individual vehicles have statistically significant differences in average consumption expressed in $\mathrm{kWh} / \mathrm{km}$.

In the last part, we focused on the regression analysis. We found a regression function, which can help dispatchers calculate the driving distance according to the battery charging state, expressed as a percentage. However, the limitation of this study remains at $R^{2}<0.6$ in determining the function for both winter and summer seasons. Both equations are very similar. We also considered the ambient temperature. However, this does not significantly affect the driving distance of the vehicle. Evaluated electric buses have independent diesel heating. This heating consumes an average of $236 \pm 59 \mathrm{~L} /$ vehicle/month in the three winter months (December, January, and February). As a result, it has a very positive effect on the consumption balance. From one percent of the battery capacity, one electric bus can run $2307 \mathrm{~km}$ in summer and $2202 \mathrm{~km}$ in winter. This difference is almost negligible. We can say that the operation of electric buses is very advantageous in in the range of tested temperatures.

We can compare the results obtained in our study with foreign sources. For example, in [66], the authors also examined the dependence of consumption on ambient temperature. Figure 9, which is from the mentioned study, shows a graphical dependence of these two quantities. Our buses with electric heaters have a significantly greater dependence. The consumption of electric buses is comparable to our values.

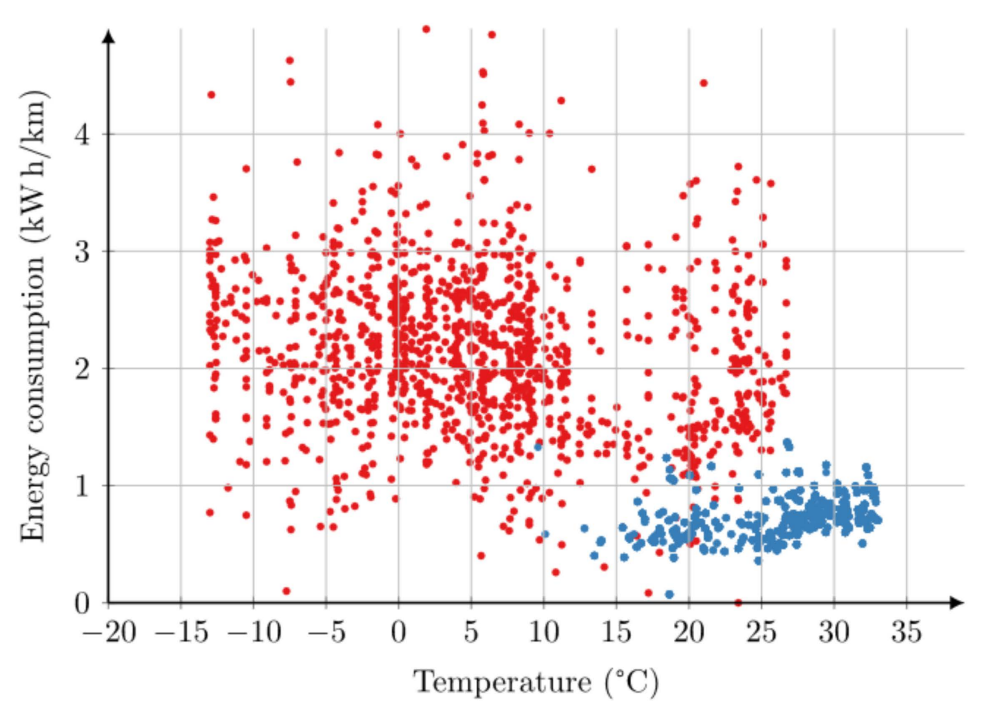

Figure 9. Observed energy consumption in $\mathrm{kWh} / \mathrm{km}$ as a function of ambient temperature (two colors $=$ two datasets) [66]. 
Study [67] also works with similar values of average electricity consumption. In this study, the authors examined not only the influence of ambient temperature but also occupancy. The study shows that the investigated electric buses had a consumption of $1.07 \mathrm{kWh} / \mathrm{km}$ in summer operation without passengers. In winter operation, they had a consumption of $1.19 \mathrm{kWh} / \mathrm{km}$. At half-occupancy, consumption was $1.31 \mathrm{kWh} / \mathrm{km}$ (summer) and $1.64 \mathrm{kWh} / \mathrm{km}$ (winter). When fully occupied by passengers, the electric bus had consumption from $1.53 \mathrm{kWh} / \mathrm{km}$ in summer to $1.93 \mathrm{kWh} / \mathrm{km}$ in winter.

Similarly, we can compare the results with [68], in which the authors used real-world data and deep learning to estimate the consumption of electric buses. Based on [69], the authors state that energy consumption depends on many parameters (bus technology, traffic conditions, number of passengers, and profile of the route) and varies between 1.0 and $3.5 \mathrm{kWh} / \mathrm{km}$.

Our research has several practical limitations. Many external factors affect electricity consumption in the urban environment. We are not able to record all of them in real conditions. These are the following factors:

1. Driver-human factor.

2. Traffic situation.

3. Geomorphology of the terrain.

4. Vehicle design and parameters (weight, rolling resistance, air resistance, etc.).

5. Vehicle load (occupancy in passenger transport).

6. Bus line (number and distance of stops).

7. Transport infrastructure (permitted speed, number of junctions, road surface, etc.).

We are aware of these influences and will investigate some of them in follow-up studies. We will record data in various ways in cooperation with the bus operator (GPS tracking, APC—automated passenger counters, or other techniques described in [70,71]).

This article brings new information regarding the energy-consumption of electric buses in the conditions of Central Europe. The most important benefits of the study are the following:

1. We found that electric buses with electric heaters show higher consumption in the winter months. This is due to the need to heat the passenger compartment.

2. Concerns about the high consumption of the electric bus in the cold season can be eliminated by suitable vehicle type. Diesel-powered electric buses show little or no dependence of electricity consumption on the ambient temperature.

3. Our study can be used when deciding on future investments of transport companies to their vehicle fleets-when buying electric buses.

4. We have analyzed and published the electricity consumption of buses in operation. They are comparable for future experiments.

5. We also showed a real fuel consumption for heating, which we want to use in future studies to calculate the exhaust emissions. Therefore, diesel-heated electric buses do not have completely zero emissions at the place of operation. This problem will be subject to further investigation.

\section{Conclusions}

The results that we published in this study can significantly improve the work of dispatchers in the deployment of electric buses in everyday operation. This article describes various advanced statistical methods and their use for evaluating the consumption of an electric bus or the entire vehicle fleet.

The research we carried out has confirmed that different electric buses have various properties. The way the passenger cabin is heated has an influence on electricity consumption in the range of tested temperatures. Therefore, the operation of electric buses needs to resolve this problem. Foreign authors, in the study [64], examined various heating options for electric buses.

The practical benefit of our research also lies in pointing out approximately the same energy consumption in winter and summer operation. It is possible to use electric buses 
even in the winter without concerns about significantly higher consumption and shorter driving distance.

Supplementary Materials: The following are available online at https://www.mdpi.com/article/ 10.3390/en14248346/s1, Table S1: Example part of the database of daily records from electric bus operation. We cannot share detailed operation data of electric buses.

Author Contributions: Conceptualization, K.Č.; methodology, K.Č.; validation, V.Š.; formal analysis, K.Č.; investigation, J.M. and K.Č.; resources, K.H.; data curation, K.Č.; writing-original draft preparation, K.Č.; writing—review and editing, K.H. and V.Š.; visualization, K.Č.; supervision, K.H. and V.Š.; project administration, K.H.; funding acquisition, K.H. All authors have read and agreed to the published version of the manuscript.

Funding: This publication was realized with support of Operational Program Integrated Infrastructure 2014-2020 of the project: Innovative Solutions for Propulsion, Power and Safety Components of Transport Vehicles, code ITMS 313011V334, co-financed by the European Regional Development Fund.

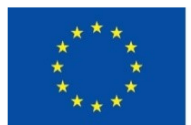

EUROPEAN UNION

European Regional Development Fund

OP Integrated Infrastructure 2014 - 2020

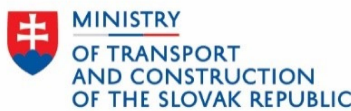

Institutional Review Board Statement: Not applicable.

Informed Consent Statement: Not applicable.

Data Availability Statement: Data available on request due to restrictions of transport enterprises.

Conflicts of Interest: The authors declare no conflict of interest.

\section{References}

1. Małek, A.; Caban, J.; Wojciechowski, L. Charging electric cars as a way to increase the use of energy produced from RES. Open Eng. 2020, 10, 98-104. [CrossRef]

2. Dižo, J.; Blatnický, M.; Semenov, S.; Mikhailov, E.; Kostrzewski, M.; Droździel, P.; Št'astniak, P. Electric and plug-in hybrid vehicles and their infrastructure in a particular European region. Transp. Res. Procedia 2021, 55, 629-636. [CrossRef]

3. Caban, J.; Vrabel, J.; Šarkan, B.; Zarajczyk, J.; Marczuk, A. Analysis of the market of electric tractors in agricultural production. MATEC Web Conf. 2018, 244, 03005. [CrossRef]

4. Grünjes, H.G.; Birkner, M. Electro mobility for heavy duty vehicles (HDV): The Siemens eHighway System. In Proceedings of the HVTT12: 12th International Symposium on Heavy Vehicle Transport Technology, Stockholm, Sweden, 16-19 September 2012.

5. Połom, M.; Wiśniewski, P. Implementing Electromobility in Public Transport in Poland in 1990-2020. A Review of Experiences and Evaluation of the Current Development Directions. Sustainability 2021, 13, 4009. [CrossRef]

6. Caban, J.; Zarajczyk, J.; Małek, A. Possibilities of using electric drives in city buses. In Proceedings of the 23rd International Scientific Conference Transport Means, Palanga, Lithuania, 2-4 October 2019; pp. 543-547.

7. Marczak, H.; Droździel, P. Analysis of Pollutants Emission into the Air at the Stage of an Electric Vehicle Operation. J. Ecol. Eng. 2021, 22, 182-188. [CrossRef]

8. Alwesabi, Y.; Liu, Z.; Kwon, S.; Wang, Y. A novel integration of scheduling and dynamic wireless charging planning models of battery electric buses. Energy 2021, 230, 120806. [CrossRef]

9. Liu, H.; Wang, D.Z.W. Locating multiple types of charging facilities for battery electric vehicles. Transp. Res. Part B Methodol. 2017, 103, 30-55. [CrossRef]

10. Jing, W.; An, K.; Ramezani, M.; Kim, I. Location design of electric vehicle charging facilities: A path-distance constrained stochastic user equilibrium approach. J. Adv. Transp. 2017, 2017, 1-15. [CrossRef]

11. Ribau, J.; Viegas, R.; Angelino, A.; Moutinho, A.; Silva, C. A new offline optimization approach for designing a fuel cell hybrid bus. Transp. Res. Part C Emerg. Technol. 2014, 42, 14-27. [CrossRef]

12. Małek, A.; Taccani, R.; Kasperek, D.; Hunicz, J. Optimization of energy management in a city bus powered by the hydrogen fuel cells. Commun. Sci. Lett. Univ. Zilina 2021, 23, E56-E67. [CrossRef]

13. Yang, C.; Jiao, X.; Li, L.; Zhang, Y.; Zhang, L.; Song, J. Robust coordinated control for hybrid electric bus with single-shaft parallel hybrid powertrain. IET Control. Theory Appl. 2015, 9, 270-282. [CrossRef]

14. Małek, A.; Niewczas, A. Selected maintenance aspects of traction batteries in electric vehicles. In Proceedings of the 12th International Science-Technical Conference AUTOMOTIVE SAFETY, Kielce, Poland, 21-23 October 2020; Volume 2020, p. 9293492.

15. Hołyszko, P.; Zieliński, D.; Niewczas, A.; Rymarz, J.; Dębicka, E. ensuring the continuity of power supply to the on-board auxiliary devices of the trolleybus through the recuperation of kinetic energy. Energies 2021, 14, 5035. [CrossRef] 
16. Hu, X.; Murgovski, N.; Johannesson, L.; Egardt, B. Energy efficiency analysis of a series plug-in hybrid electric bus with different energy management strategies and battery sizes. Appl. Energy 2013, 111, 1001-1009. [CrossRef]

17. Zhang, S.; Xiong, R.; Zhang, C. Pontryagin's minimum principle-based power management of a dual-motor-driven electric bus. Appl. Energy 2015, 159, 370-380. [CrossRef]

18. Thein, S.; Chang, Y.S. Decision making model for lifecycle assessment of lithium-ion battery for electric vehicle-A case study for smart electric bus project in Korea. J. Power Sources 2014, 249, 142-147. [CrossRef]

19. Xiong, W.; Zhang, Y.; Yin, C. Optimal energy management for a series-parallel hybrid electric bus. Energy Convers. Manag. 2009, 50, 1730-1738. [CrossRef]

20. Peng, J.; He, H.; Xiong, R. Rule based energy management strategy for a series-parallel plug-in hybrid electric bus optimized by dynamic programming. Appl. Energy 2017, 185, 1633-1643. [CrossRef]

21. Skrúcaný, T.; Synák, F.; Semanová, S.; Ondruš, J.; Rievaj, V. Detection of road vehicle's centre of gravity. In Proceedings of the 2018 XI International Science-Technical Conference Automotive Safety, Žastá, Slovakia, 18-20 April 2018; pp. 1-7. [CrossRef]

22. Haddadian, G.; Khodayar, M.; Shahidehpour, M. Accelerating the global adoption of electric vehicles: Barriers and drivers. Electr. J. 2015, 28, 53-68. [CrossRef]

23. Romm, J. The car and fuel of the future. Energy Policy 2006, 34, 2609-2614. [CrossRef]

24. Khan, M.; Kockelman, K.M. Predicting the market potential of plug-in electric vehicles using multiday GPS data. Energy Policy 2012, 46, 225-233. [CrossRef]

25. Karlsson, S. What are the value and implications of two-car households for the electric car? Transp. Res. Part C Emerg. Technol. 2017, 81, 1-17. [CrossRef]

26. Yan, S. The economic and environmental impacts of tax incentives for battery electric vehicles in Europe. Energy Policy 2018, 123, 53-63. [CrossRef]

27. Abotalebi, E.; Scott, D.M.; Ferguson, M.R. Can canadian households benefit economically from purchasing battery electric vehicles? Transp. Res. Part D Transp. Environ. 2019, 77, 292-302. [CrossRef]

28. Scorrano, M.; Danielis, R.; Giansoldati, M. Dissecting the total cost of ownership of fully electric cars in Italy: The impact of annual distance travelled, home charging and urban driving. Res. Transp. Econ. 2020, 80, 100799. [CrossRef]

29. Li, H.; Chen, C. Research on residual value evaluation of battery electric vehicles based on replacement cost method. IOP Conf. Series Earth Environ. Sci. 2020, 461, 12027. [CrossRef]

30. He, F.; Yin, Y.; Lawphongpanich, S. Network equilibrium models with battery electric vehicles. Transp. Res. Part B Methodol. 2014, 67, 306-319. [CrossRef]

31. Björnsson, L.; Karlsson, S. Electrification of the two-car household: PHEV or BEV? Transp. Res. Part C Emerg. Technol. 2017, 85, 363-376. [CrossRef]

32. Pearre, N.S.; Kempton, W.; Guensler, R.L.; Elango, V.V. Electric vehicles: How much range is required for a day's driving? Transp. Res. Part C Emerg. Technol. 2011, 19, 1171-1184. [CrossRef]

33. Breetz, H.L.; Salon, D. Do electric vehicles need subsidies? Ownership costs for conventional, hybrid, and electric vehicles in 14 U.S. cities. Energy Policy 2018, 120, 238-249. [CrossRef]

34. Ouyang, D.; Zhou, S.; Ou, X. The total cost of electric vehicle ownership: A consumer-oriented study of China's post-subsidy era. Energy Policy 2021, 149, 112023. [CrossRef]

35. Poliak, M.; Semanová, Š.; Mrníková, M.; Komačková, L.; Šimurková, P.; Poliaková, A.; Hernandes, S. Financing public transport services from public funds. Transp. Probl. 2017, 12, 61-72. [CrossRef]

36. Poliak, M.; Poliakova, A.; Mrnikova, M.; Simurkova, P.; Jaskiewicz, M.; Jurecki, R. The competitiveness of public transport. J. Competitiveness 2017, 9, 81-97. [CrossRef]

37. Zeng, X.; Wang, J. Stochastic optimal control for hybrid electric vehicles running on fixed routes. In Proceedings of the 2015 American Control Conference (ACC), Chicago, IL, USA, 1-3 July 2015; pp. 3273-3278. [CrossRef]

38. Pirooz, A.; Gandoman, F.H.; Firouz, Y.; Van Mierlo, J. Feasibility study of reconfigurability between different power transmission concepts for electric bus charging. In Proceedings of the Transport Research Arena 2020: Rethinking Transport, Helsinki, Finland, 27-30 April 2020.

39. Chen, Z.; Liu, W.; Yin, Y. Deployment of stationary and dynamic charging infrastructure for electric vehicles along traffic corridors. Transp. Res. Part C Emerg. Technol. 2017, 77, 185-206. [CrossRef]

40. Xi, X.; Sioshansi, R.; Marano, V.; Ann Arbor, M.I. Simulation-optimization model for location of a public electric vehicle charging infrastructure. Transp. Res. Part D Transp. Environ. 2013, 22, 60-69. [CrossRef]

41. Raposo, J.; Rodrigues, A.; Silva, C.; Dentinho, T. A multi-criteria decision aid methodology to design electric vehicles public charging networks. AIP Adv. 2015, 5, 057123. [CrossRef]

42. Huang, K.; Kanaroglou, P.; Zhang, X. The design of electric vehicle charging network. Transp. Res. Part D Transp. Environ. 2016, 49, 1-17. [CrossRef]

43. Ministry of Economy of the Slovak Republic: Electromobility in the Slovak Republic in Numbers. Available online: https:/ / emobility.sk/wp-content/uploads/2020/08/Elektromobilita-v-\%C4\%8D\%C3\%ADslach-Q2-2020.pdf (accessed on 22 June 2021).

44. Verkehr, S.C.I. Share of Electric Buses Worldwide in 2018, by Key Region [Graph]. In Statista. 12 August 2020. Available online: https:/ / www.statista.com/statistics/1139184/global-electric-bus-fleet-by-region/ (accessed on 22 June 2021). 
45. Ministry of Interior of the Slovak Republic: The Total Number of Registered Vehicles in the Slovak Republic. Available online: https://www.minv.sk/?celkovy-pocet-evidovanych-vozidiel-v-sr (accessed on 22 June 2021).

46. Slovak Hydrometeorological Institute: Near Real Time Data of Selected Station Network. Available online: http://www.shmu. sk/sk/?page=1\&id=klimat_operativneudaje1 (accessed on 22 June 2021).

47. Evidencia-Dopravcov.eu: Database of Vehicles of Slovak Carriers. Available online: https://evidencia-dopravcov.eu/ (accessed on 22 June 2021).

48. SOR.cz: EBN. Available online: https://www.sor.cz/wp-content/uploads/2017/09/EBN_8-95-11_CZ_LoRes.pdf (accessed on 22 June 2021).

49. Imhd.sk: Bratislava-Vehicles-Buses. Available online: https://imhd.sk/ba/popis-typu-vozidla/860/SOR-EBN-8 (accessed on 22 June 2021).

50. SOR.cz: NS 12 Electric. Available online: https://www.sor.cz/wp-content/uploads/2019/11/NS_12_electric_CZ_NEW2_LoRes_ 23.10.2019.pdf (accessed on 22 June 2021).

51. Imhd.sk: Bratislava-Vehicles-Buses. Available online: https://imhd.sk/ba/popis-typu-vozidla/861/SOR-NS-12-Electric (accessed on 22 June 2021).

52. Gao, Y.; Guo, S.; Ren, J.; Zhao, Z.; Ehsan, A.; Zheng, Y. An electric bus power consumption model and optimization of charging scheduling concerning multi-external factors. Energies 2018, 11, 2060. [CrossRef]

53. Wu, Z.; Guo, F.; Polak, J.; Strbac, G. Evaluating grid-interactive electric bus operation and demand response with load management tariff. Appl. Energy 2019, 255, 113798. [CrossRef]

54. Paffumi, E.; Martini, G. Real-world mobility and environmental data for the assessment of in-vehicle battery capacity fade. World Electr. Veh. J. 2021, 12, 48. [CrossRef]

55. Wang, J.; Purewal, J.; Liu, P.; Hicks-Garner, J.; Soukazian, S.; Sherman, E.; Sorenson, A.; Vu, L.; Tataria, H.; Verbrugge, M.W Degradation of lithium ion batteries employing graphite negatives and nickel-cobalt-manganese oxide + spinel manganese oxide positives: Part 1, aging mechanisms and life estimation. J. Power Sources 2014, 269, 937-948. [CrossRef]

56. Wang, D.; Coignard, J.; Zeng, T.; Zhang, C.; Saxena, S. Quantifying electric vehicle battery degradation from driving vs. vehicle-to-grid services. J. Power Sources 2016, 332, 193-203. [CrossRef]

57. Konečný, V.; Poliak, M.; Poliaková, A. Ekonomická Analýza Podniku Cestnej Dopravy; EDIS-Vydavatel'stvo ŽU: Žilina, Slovakia, 2010.

58. Cohen, J. Statistical Power Analysis for the Behavioral Sciences, 2nd ed.; Á/L. Erbaum Press: Hillsdale, NJ, USA, 1988.

59. Sebera, M. Multidimensional Statistical Methods. Available online: https://www.fsps.muni.cz/ \{\} sebera/vicerozmerna_ statistika/anova.html (accessed on 28 June 2021).

60. Hebák, P.; Hustopecký, J.; Jarošová, E.; Pecáková, I. Vícerozměrné Statistické Metody 1, 1st ed.; Informatorium: Prague, Czech Republic, 2007; pp. 160-161.

61. Skoda Electric: Electric Buses with Standard Charging. Available online: https://www.skoda.cz/reference/elektrobusy-sestandardnim-dobijenim/ (accessed on 26 November 2021).

62. Climate \& Weather Averages in Bratislava, Slovakia. Available online: https://www.timeanddate.com/weather/slovakia/ bratislava/climate (accessed on 28 June 2021).

63. Meteocentrum.sk: Meteorological Station Most Pri Bratislave. Available online: http://meteocentrum.sk/most/wxtempdetail php? year=2019 (accessed on 28 June 2021).

64. Kraft, W.; Stahl, V.; Vetter, P. Thermal Storage Using Metallic Phase Change Materials for Bus Heating-State of the Art of Electric Buses and Requirements for the Storage System. Energies 2020, 13, 3023. [CrossRef]

65. Jefferies, D.; Ly, T.; Kunith, A.; Göhlich, D. Energiebedarf Verschiedener Klimatisierungssysteme Für Elektro-Linienbusse; Deutsche Kälte-und Klimatagung: Dresden, Germany, 2015.

66. Hjelkrem, O.A.; Lervåg, K.Y.; Babri, S.; Lu, C.; Södersten, C.-J. A battery electric bus energy consumption model for strategic purposes: Validation of a proposed model structure with data from bus fleets in China and Norway. Transp. Res. Part D Transp. Environ. 2021, 94, 102804. [CrossRef]

67. Algin, V.; Goman, A.; Skorokhodov, A.; Bytsko, O.; Chistov, S.; Fedasenka, S. Methodology for probabilistic assessment of energy consumption by electric buses on routes. In Electric Mobility in Public Transport_Driving Towards Cleaner Air; Springer: Cham, Switzerland, 2021; pp. 83-105. [CrossRef]

68. Pamuła, T.; Pamuła, W. Estimation of the energy consumption of battery electric buses for public transport networks using real-world data and deep learning. Energies 2020, 13, 2340. [CrossRef]

69. Vepsäläinen, J.; Ritari, A.; Lajunen, A.; Kivekäs, K.; Tammi, K. Energy uncertainty analysis of electric buses. Energies 2018, $11,3267$. [CrossRef]

70. Kalašová, A.; Černický, L'.; Kupčuljaková, J. The impact of public transport priority on the traffic in the chosen part of the city of Žilina. Transp. Probl. 2014, 9, 19-26.

71. Ondruš, J.; Kolla, E.; Vertal', P.; Šarić, Ž. How Do Autonomous Cars Work? Transp. Res. Procedia 2020, 44, 226-233. [CrossRef] 